\title{
Congenital anterior mediastinal teratoma causing severe airway compression in a neonate
}

\author{
Adrie Bekker, ${ }^{1}$ Pierre Goussard, ${ }^{1}$ Robert Gie, ${ }^{1}$ Savvas Andronikou ${ }^{2}$
}

${ }^{1}$ Department of Pediatrics and Child Health, Stellenbosch University, Tygerberg Children's Hospital, Cape Town, South Africa

2Department of Radiology, Witwatersrand University, Johannesburg, South Africa

\section{Correspondence to}

Dr Pierre Goussard,

pgouss@sun.ac.za

\section{DESCRIPTION}

A newborn, weighing $2200 \mathrm{~g}$, was delivered through caesarean section, at 35 weeks gestational age, for fetal distress. No antenatal scan had been performed. The neonate presented with severe respiratory distress shortly after birth and requiring urgent intubation. The chest X-ray (figure 1A) revealed a wide mediastinum with poor visualisation of the trachea. A tracheobronchogram, using water-soluble contrast medium (figure 1B), performed in the neonatal intensive care unit demonstrated severe narrowing of the trachea from tracheal midpoint up to and including the carina and origins of both main bronchi. The echocardiography confirmed a structurally normal heart. In addition a cystic fluid filled mass in the anteriorsuperior mediastinum was visualised. At flexible bronchoscopy anterior compression of the trachea with no structural tracheal stenosis was demonstrated. The chest CT (figure 2) confirmed a large, predominately low-density, non-enhancing, heterogeneous mass in the anterior mediastinum with posterior displacement and critical circumferential narrowing of the trachea. A congenital teratoma was suspected and complete surgical excision of the mass $(60 \times 40 \times 22 \mathrm{~mm})$ was performed on day 5 of life. Histology confirmed a benign grade 1 immature teratoma originating from the thymus. The neonate was successfully extubated 9 days postoperatively and made an uneventful recovery. At follow-up the infant remained asymptomatic.

Fetal mediastinal teratomas represent only $10 \%$ of congenital teratomas. Congenital mediastinal

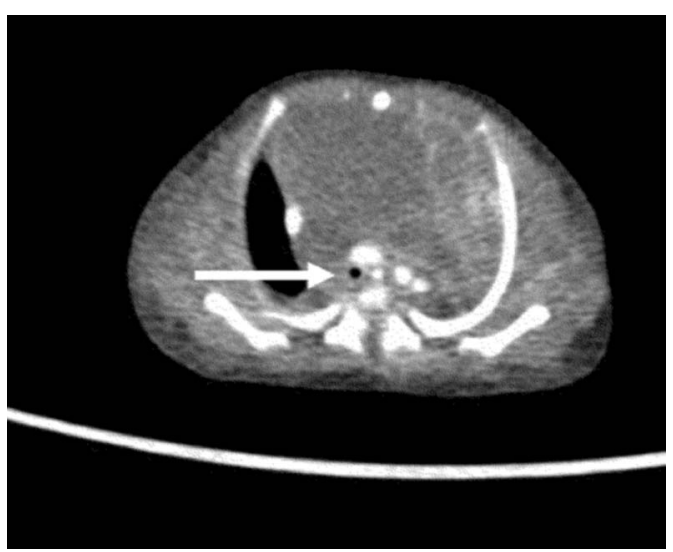

Figure 2 Axial CT scan after intravenous contrast injection demonstrates posterior displacement of the great vessels, trachea and oesophagus as well as circumferential severe narrowing of the trachea (arrow) caused by a large anterior mediastinal mass of predominantly low density with minimal peripheral heterogenous enhancement. The mass origin was presumed to be the thymus.

teratomas are rare congenital abnormalities. ${ }^{1}$ These lesions can present with unmanageable airway compression and acute cardiorespiratory failure. ${ }^{2}$ Treatment requires immediate recognition and complete surgical excision of the lesion. $\alpha$-Fetoprotein blood levels can be used to monitor the presence of tumour cells. ${ }^{3}$ Before and after surgery these values were 60390.8 and $9361.7 \mu \mathrm{g} / \mathrm{L}$, respectively in our patient.

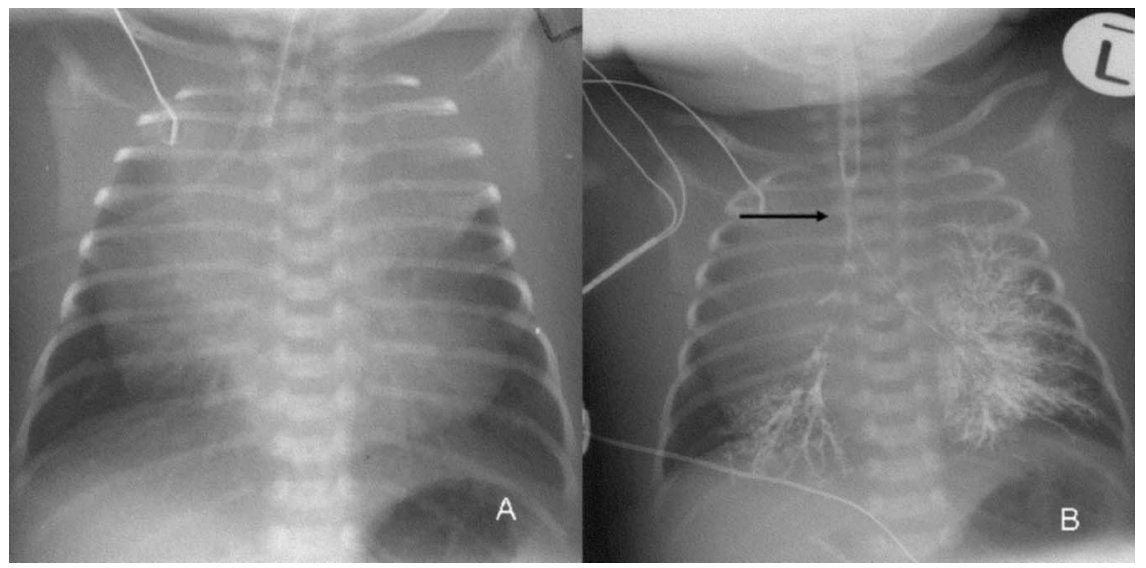

To cite: Bekker $A$ Goussard P, Gie R, et al BMJ Case Rep Published online: [please include Day Month Year] doi:10.1136/ bcr-2013-201205
Figure 1 Plain frontal radiograph and frontal radiograph with tracheobronchography using a water-soluble contrast agent performed in the neonatal intensive care unit (ICU). (A) The frontal radiograph demonstrates an endotracheal tube in situ while the lower portions of the trachea are indistinct and presumed compressed. The wide mediastinum in the presence of a compressed trachea is therefore presumed to be pathological and suggestive of an anterior mediastinal mass possibly arising from the thymus. (B) Tracheobronchography performed using $2 \mathrm{~mL}$ of low-osmolar water-soluble contrast administered through the endotracheal tube was performed and in the neonatal ICU confirms severe narrowing of the midtrachea to lower trachea (arrow) presumably due to an anterior medistinal mass. 
Other congenital mediastinal lesions that can present in the newborn period include bronchogenic cysts, bronchopulmonary foregut malformations, lymphangiomas and neuroblastomas. These congenital malformations can be suspected on fetal antenatal scanning so that optimal management can be planned.

\section{Learning points}

- Congenital teratoma can be the cause of an anterior mediastinal mass in a neonate.

- Congenital teratoma can cause significant airway compression in a neonate.

- Tracheobronchogram may be a useful investigation in neonates with suspected airway obstruction.
Contributors $A B$ was the treating doctor in this case. PG and RG were responsible for the investigation and the decisions about surgery. SA was responsible for the radiological investigations.

Competing interests None.

Patient consent Obtained.

Provenance and peer review Not commissioned; externally peer reviewed.

\section{REFERENCES}

1 Schild RL, Plath H, Hofstaetter C, et al. Prenatal diagnosis of a fetal mediastinal teratoma. Ultrasound Obstet Gynecol 1998;12:369-70.

2 Tsao K, Albanese CT, Harrison MR. Prenatal therapy for thoracic and mediastinal lesions. World J Surg 2003;27:77-83.

3 Tjalma WA. The value of AFP in congenital cervical teratoma. J Pediatr Surg 2003;38:1846.

Copyright 2013 BMJ Publishing Group. All rights reserved. For permission to reuse any of this content visit

http://group.bmj.com/group/rights-licensing/permissions.

BMJ Case Report Fellows may re-use this article for personal use and teaching without any further permission.

Become a Fellow of BMJ Case Reports today and you can:

- Submit as many cases as you like

- Enjoy fast sympathetic peer review and rapid publication of accepted articles

- Access all the published articles

- Re-use any of the published material for personal use and teaching without further permission

For information on Institutional Fellowships contact consortiasales@bmjgroup.com

Visit casereports.bmj.com for more articles like this and to become a Fellow 